\title{
Residual Potential of Dexamethasone and its Effect on Goat Milk
}

\author{
Muhammad Atif Khan ${ }^{1}$, Shamsuddin Bughio ${ }^{1 *}$, Rehana Buriro ${ }^{1}$, Muhammad Bilawal Arain ${ }^{1}$, Saeed Ahmed Soomro ${ }^{2}$, \\ Gulfam Ali Mughal ${ }^{3}$ and Zainab Lanjar ${ }^{1}$ \\ ${ }^{1}$ Department of Veterinary Pharmacology, Sindh Agriculture University, Tandojam 70064, Pakistan \\ ${ }^{2}$ Department of Veterinary Physiology and Biochemistry Sindh Agriculture University, Tandojam 70064, Pakistan \\ ${ }^{3}$ Department of Animal Nutrition, Sindh Agriculture University, Tandojam 70064, Pakistan \\ *For correspondence: shams_bughio@yahoo.com \\ Received 07 October 2021; Accepted 20 November 2021; Published 30 January 2022
}

\begin{abstract}
The aim of this study was to analyse the effect of intramuscular administration of dexamethasone (DXM) on clinical, residual and milk composition parameters in goat. For this, $0.5 \mathrm{mg} / \mathrm{kg}$ BW dose of DXM was administered once daily for 3 consecutive days. Milk samples were collected before and after drug administration at 2, 8, 16, 32, 48, 72, 96, 120, 144, 168 h. Pulse rate and respiratory rate were increased $(P<0.05)$ in at 2, 8, 16, 32, 48 and 72 and $96 \mathrm{~h}$ While, the rectal temperature was increased $(P<0.05)$ only at $02 \mathrm{~h}$ post drug administration. The highest residual level of DXM was noticed at $32 \mathrm{~h}(2.70$ $\mathrm{ng} / \mathrm{mL})$ and lowest at $168 \mathrm{~h}(0.25 \mathrm{ng} / \mathrm{mL})$ in milk. Milk Fat increased $(P<0.01)$ at 32, 48 and $72 \mathrm{~h}$ and $(P<0.05)$ at $2,8,16$, $96,120 \mathrm{~h}$ and then gradually returned to pre-treatment value at $144 \mathrm{~h}$. The mean milk protein level was increased $(P<0.01)$ at $8,16,32,48,72$ and $120 \mathrm{~h}$ and $(P<0.05)$ at 2 and $96 \mathrm{~h}$. Milk Solid Not Fat level was increased $(P<0.05)$ at 16, 32, 48, 72 and $96 \mathrm{~h}$, however, at $120 \mathrm{~h}$ this increase was $(P<0.01)$. Milk yield decreased $(P>0.05)$ from $2-16 \mathrm{~h}$ as compared to control then, decreased $(P<0.05)$ at 32, 48, 72, 96, 120, $144 \mathrm{~h}$ post DXM administration. It has been concluded that the therapeutic dose of DXM $0.5 \mathrm{mg} / \mathrm{kg}$ BW once daily for 3 consecutive days produced significant effects on clinical, residual level and milk composition parameters in goat. (C) 2022 Friends Science Publishers
\end{abstract}

Keyword: Dexamethasone; Goat; Milk; Potential; Residues

\section{Introduction}

Milk secretion from mammary glands is the main characteristic of all female mammals. The natural milk is important for young ones because it contains complete nutrients like carbohydrates, proteins, minerals and vitamins in an appropriate amount with little bit variation among various species of animals (Roadhouse and Henderson 1950). Within a particular specie, genetic factors, environmental conditions such as climate and stage of lactation may also affect the composition of milk. Usage of various drugs may also affect the quantity and quality of milk. Among drugs, corticosteroids are commonly used agents in Animals. Corticosteroids are a big group of naturally occurring and synthetic chemical compounds used in veterinary as well as in human medicine. Corticosteroids are immunosuppressive, anti-inflammatory and also important for carbohydrate, lipid metabolism, regulation of blood pressure and maintenance of muscle tone and bone density (Kufe et al. 2003).

Among corticosteroids, Dexamethasone is a synthetic corticosteroid and has pharmacological effects including anti-inflammatory, anti-toxic, anti-allergic and antirheumatic activities. Therefore, it is widely used in veterinary clinical treatment of maternal metabolic diseases to treat infectious diseases and it is also one of the commonly used drugs in livestock. However, DXM can also cause certain adverse reactions to animals, such as gastrointestinal reactions, allergic reactions, liver dysfunction, skin and mucosal symptoms. Therefore, DXM is strictly forbidden to be used as a growth hormone in animal-derived food globally. Many countries and organizations have established the maximum residue limits (MRLs) for DXM in animal foods (Li et al. 2021). (DXM) is commonly used as a therapeutic as well as in in high doses to treat chronic inflammatory and autoimmune diseases, some neurological disease and to prevent hypersensitivity reactions associated with certain medications (Sousa 2005; Ito et al. 2006). It has been reported that the long-term use of low concentrations of DXM may have adverse effects on public health (Becker 2011; Reig et al. 2016). DXM residues has been reported in the various biological samples such as urine, feces, meat, milk and liver in different animals (Chen et al. 2011; Cherlet et al. 2014). Importantly, their therapeutic use has also been restricted because of its concentration above the maximum residue limits (MRLs) in milk and edible tissues. The MRLs of DXM in milk samples are $0.3 \mu \mathrm{g} / \mathrm{kg}$. Reportedly, DXM residues may also affect milk composition in various species 
(Macrina et al. 2014). Due to the frequent use of DXM in various illnesses, it may produce residues in dairy and other products of animal origin aimed for human consumption. Hence, it is necessary to develop comprehensive control measures to monitor DXM residues in goat milk because goat milk is commonly consumed by children. Considering the limited information on DXM residues its effects on clinical and on the milk composition, this study was designed to assess the residual potential of DXM, its effects on clinical and on the milk composition in local goat breeds.

\section{Materials and Methods}

\section{Experimental Protocol}

Six lactating healthy goats of mix breeds were used in present study. The goats were kept indoor at Livestock Experimental Station, Sindh Agriculture University Tandojam. The animals were acclimatized for three weeks. All animals were dewormed and vaccinated before start of the experiment. All animals were identified by the use of an ear tag assigned a number from G1 to G6. Dexamethasone (DXM) (Dexafar, Farvet Pharmaceutical company) was administered intramuscularly to evaluate its residual profile and its effect on clinical and on goat milk composition.

\section{Treatment procedure}

Milk samples were collected before as a control and after drug administration. DXM was administered at a therapeutic dose of $0.5 \mathrm{mg} / \mathrm{kg} \mathrm{BW}$ intramuscularly (I.M.) for 03 consecutive days once daily to six healthy lactating dairy goats (based on high yield lactating animals). Then, milk samples were collected at 2, 8, 16, 32, 48, 72, 96, 120, 144 and $168 \mathrm{~h}$ post drug administration. Milk samples were collected in two set of test tubes, one set containing $5 \mathrm{~mL}$ for residual analysis which was kept at $-35^{\circ} \mathrm{C}$ until analysis and another set of test tube having $100 \mathrm{~mL}$ for milk composition which was analyzed immediately. The effect of DXM on milk composition and its analysis was investigated at the Department of Animal Products Technology, Sindh Agriculture University, Tandojam. For residual analysis, milk samples were brought in ice bags to Veterinary Research Institute Peshawar, Khyber Pakhtunkhwa.

\section{Clinical parameters}

Vitals: Pulse rate (PR), Respiratory rate (RR) and rectal temperature (RT) recorded before administration of DXM and after 2, 8, 16, 32, 48, 72, 96, 120, 144 and $168 \mathrm{~h}$ post dosage regimen respectively.

\section{Analysis of milk}

Fat content: For the determination of fat content, Gerber method was used as described by Kleyn et al. (2001).
Briefly, $11 \mathrm{~mL}$ milk sample was mixed with $10 \mathrm{~mL}$ of $90 \%$ sulfuric acid and $01 \mathrm{~mL}$ amyl alcohol in Butyrometer and then closed with a rubber cork. The Butyrometer was placed in a Gerber machine and centrifuged for $05 \mathrm{~min}$ at 1100 $\mathrm{rpm}$. The percentage of fat was identified on the scale of butyrometer.

Protein content: Protein content determination was carried according to Barbano et al. (1999). Briefly, a $05 \mathrm{~mL}$ milk sample was used in Micro-Kjeldahl digester in the existence of catalyst $0.2 \mathrm{~g} \mathrm{CuSO}_{4}$ and $02 \mathrm{~g}$ Sodium/Potassium Sulphate where $30 \mathrm{~mL} \mathrm{H} \mathrm{H}_{2} \mathrm{SO}_{4}$ was used. The digested sample was diluted by adding $250 \mathrm{~mL}$ distilled water. Subsequently, $05 \mathrm{~mL}$ diluted sample was taken and distilled with $40 \%$ of Sodium hydroxide using Micro-Kjeldahl distillation unit where steam was distilled in $05 \mathrm{~mL}$ of $2 \%$ $\mathrm{H}_{3} \mathrm{BO}_{3}$ (Boric acid) containing an indicator for $03 \mathrm{~min}$. The Ammonia trapped in $\mathrm{H}_{3} \mathrm{BO}_{3}$ and was determined by titrating with $0.1 \mathrm{~N} \mathrm{HCl}$. The Nitrogen Percentage was analyzed using the formula written as under:

$\mathrm{N} \%=\frac{1.4(V 1-V 2) \times \text { normality of } \mathrm{HCl}}{\text { Weight of taken sample } \times \text { Volume of Blank Sample }} \times 250$

Where;

V1=Value of titrated milk sample

V2= Value of titrated blank sample

Protein content was evaluated by modifying nitrogen percentage to protein, believing that, all nitrogen was available in milk as a protein ie, protein percentage $=\mathrm{N} \% \times$ conversion factor. Conversion factor $=100 / \mathrm{N} \%$ in milk products (i.e., 15.66).

Lactose content: Milk Lactose determination was done through difference method using the following formula: Lactose $\%=\mathrm{TS} \%-($ Fat $\%+$ Protein $\%+$ Ash $\%)$

Solid not fat content (SNF): Determination of SNF content in milk was performed by difference method using following formula: Solid Not Fat $\%=$ TS $\%$ - Fat $\%$

Residual detection: The residues of DXM in goat's milk were determined using Direct Competitive ELISA (AgraQuant ${ }^{\circledR}$ COKDA0800) according to manufacturer's instructions.

\section{Statistical analyses}

Statistical analysis was performed using a computer program, Student Edition of Statistic (SXW), Version 8.1 (Copyright 2005, Analytical Software, USA). Further, data were analyzed by linear models, where analysis of variance with three- way ANOVA was done in case of significant difference existed; the means were additional computed applying least significant difference (LSD) test at 5 and $1 \%$ probability level.

\section{Results}

This study was aimed to observe various effects associated with the short-term administration of dexamethasone (DXM) in goat species. 


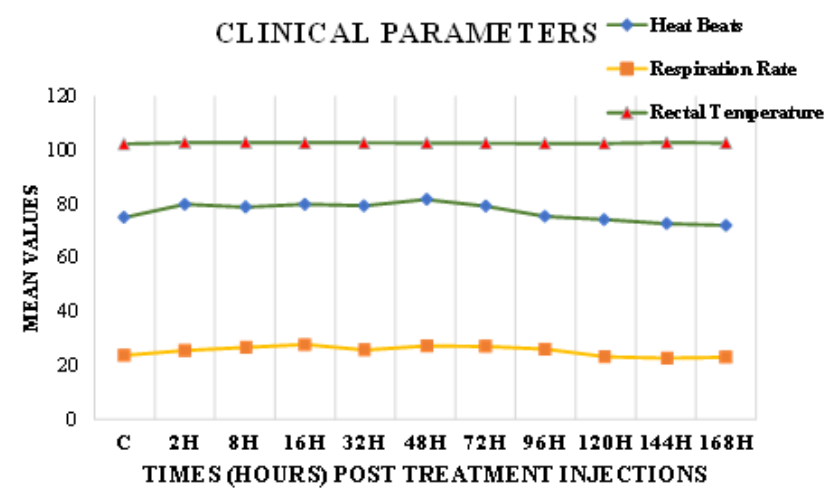

Fig. 1: Mean values of Clinical Parameters of goats $(n=6)$ obtained after I/M administration of dexamethasone

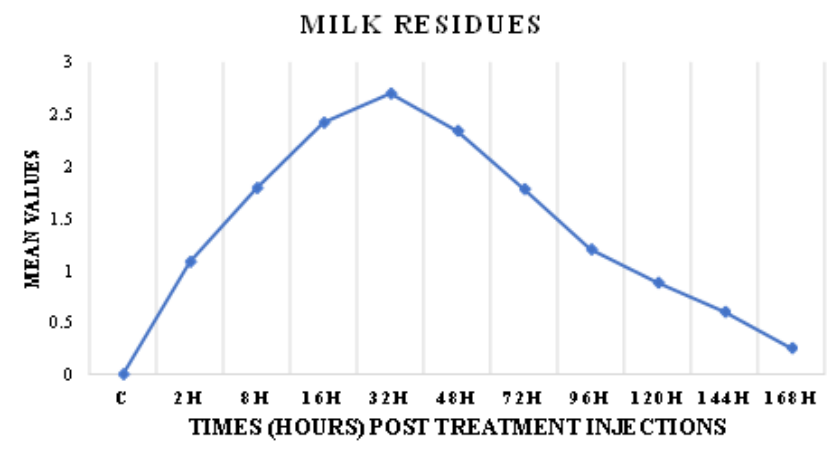

Fig. 2: Residue analysis of intramuscularly administered dexamethasone at the therapeutic dose of $0.5 \mathrm{mg} / \mathrm{kg} \mathrm{BW}$ once daily for 3 consecutive days in goat $(n=6)$ milk

\section{Clinical parameters}

\section{Heartbeat, respiratory rate, rectal temperature}

Pulse rate was increased $(P<0.05)$ at various time-points from $8-96 \mathrm{~h}$ however, it was decreased $(P<0.05)$ at $168 \mathrm{~h}$ as compared to control. The respiratory rate was increased $(P<0.05)$ at $2 \mathrm{~h}$ and at $8,16,32,48,72$ and $96 \mathrm{~h}(P<0.01)$ post-DXM administration. The maximum increase of respiratory rate was noticed at $16 \mathrm{~h}$ after treatment. Afterward, the respiratory rate gradually returned to control value at $168 \mathrm{~h}$. The rectal temperature was increased $(P<0.05)$ at $02 \mathrm{~h}$ post-treatment, while, this increase was $(P>0.05)$ in subsequent hour in comparison to control (Fig. 1).

\section{Dexamethasone residues in milk}

Administration of DEX increased $(P<0.01)$ its residual level at $02,08,16,32,48,72,96,120$ and 144 h. However, statistical analysis showed $(P>0.05)$ increased value at 168 $\mathrm{h}$. The highest and lowest mean values of DEX residues in goat milk were found at 32 and $168 \mathrm{~h}$ following DEX administration respectively (Fig. 2).

\section{Effect of dexamethasone on the composition of milk}

Milk fat: DXM administration increased $(P<0.05)$ milk fat content at 2, 8, 16, 96 and $120 \mathrm{~h}$ as compared to control whereas, this increased $(P<0.01)$ was perceived at 32,48 and $72 \mathrm{~h}$. The highest and lowest mean values of milk fat were noticed at 48 and $144 \mathrm{~h}$ post drug administration respectively. The milk fat values at 144 and $168 \mathrm{~h}$ were found statistically $(P>0.05)$ as compared to control (Fig. 3).

Milk protein: DXM administration increased $(P<0.05)$ at 2 and $96 \mathrm{~h}$, whereas, at 8, 16, 32, 48, 72 and $120 \mathrm{~h}$ increased $(P<0.01)$ milk protein level. The highest and lowest mean values of milk protein level were detected at 48 and $144 \mathrm{~h}$ post drug administration respectively. At 144 and $168 \mathrm{~h}$, the values showed a non-significant difference with the control value (Fig. 3).

Milk sugar (lactose): The therapeutic dose of DXM showed the $(P>0.05)$ - in milk lactose level at all designated time points of observations as compared to control (Fig. 3).

SNF: The administration of DXM increased $(P<0.05)$ at $16,32,48,72$ and $96 \mathrm{~h}$, however, at $120 \mathrm{~h}$, this increase was $(P<0.01)$. Then, the values at 144 and $168 \mathrm{~h}$ gradually returned to pre-treatment level and were found $(P>0.05)$ as compared to control value. The highest and lowest mean values of SNF were apparent at 120 and $168 \mathrm{~h}$ post drug administration respectively (Fig. 3).

Milk yield: DXM-induced effects caused decreased $(P>$ $0.05)$ in milk yield $2-16 \mathrm{~h}(203.83 \pm 9.27)$, as compared to pre-treatment observations, thereafter, a significantly decreased $(P<0.05)$. However, milk yield returned to control value at $168 \mathrm{~h}(206.67 \pm 9.60)$ in lactating goats (Fig. 4).

\section{Discussion}

In current study, DXM at therapeutic dose of $0.5 \mathrm{mg} / \mathrm{kg} \mathrm{BW}$ once daily for 03 days was administered intramuscularly to observe its residual, clinical and its effects on milk composition in goats. It was noticed that clinical indicators i.e., pulse rate, respiration rate and rectal temperature (Fig. 1) were increased following the administration of DXM. The current study showed agreement with previous studies where it was also described (Becker 2011) that corticosteroids exhibits its effects on CVS as a result of its effect on plasma volume, and electrolyte balance, synthesis of adrenaline and angiotensin levels, all of which leading in maintaining normal blood pressure and cardiac output. Corticosteroids have effects on the heart muscle responses, permeability fluid and electrolyte balance concerned with proper carbohydrate, lipid metabolism, regulation of blood pressure, and bone density (Becker 2011). The increase in pulse rate (cardiac output) as well as the blood pressure has also been reported with DXM treatment. Increase in pulse rate and blood pressure have been observed in infants 


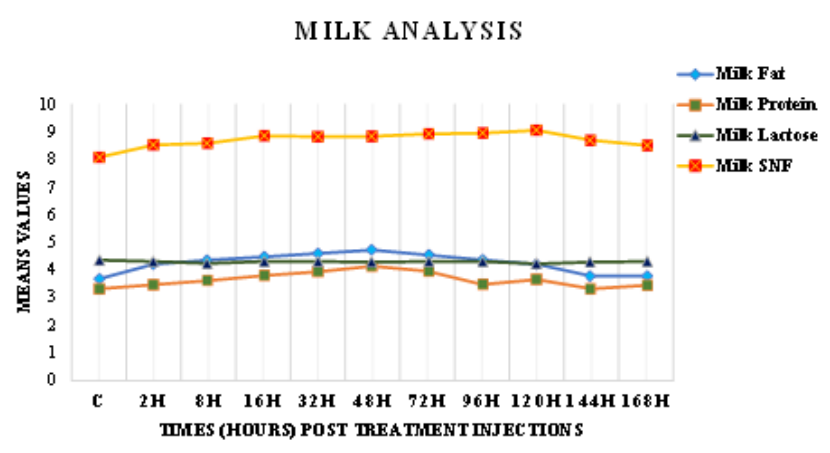

Fig. 3: Mean values of Milk analysis of goats $(n=6)$ obtained after administration of $\mathrm{I} / \mathrm{M}$ dexamethasone once daily for 03 days

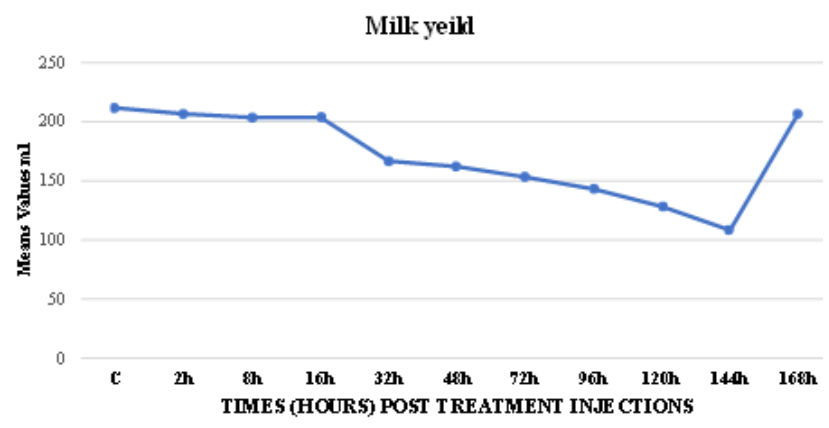

Fig. 4: Mean values milk yield of goats $(n=6)$ obtained after administration of $\mathrm{I} / \mathrm{M}$ dexamethasone

(Fauser et al. 1993; Washburn et al. 2003). The increase in respiratory rate in this study is also in accordance with the previous findings reported by Ohlsson et al. (1992) and Durand et al. (2002)) in humans and animals. It was stated that glucocorticoids have a positive inotropic effect on the cardiopulmonary system. It stimulates heart muscle contraction and increases heart rate, this increase in heart rate and cardiac output increases the volume of blood flow (Washburn et al. 2003). This increased blood flow with $\mathrm{CO}_{2}$ crosses blood brain and blood CSF barriers. $\mathrm{CO}_{2}$ combines with $\mathrm{H}_{2} \mathrm{O}$ to form $\mathrm{H}_{2} \mathrm{CO}_{3}$ that dissociates into $\mathrm{HCO}_{3}$ Ions and $\mathrm{H}^{+}$ions. This $\mathrm{H}^{+}$stimulates chemo-sensitive area (Carotid bodies at the bifurcation of common carotid arteries). It has been reported in fetal sheep that the increased respiration and blood pressure in part is related to the glucocorticoid-induced increased pulmonary angiotensin conversion enzyme (ACE) (Zimmermann et al. 2003). The increase in rectal temperature in this study is supported by previous findings of Coelho et al. (1995) and Yared et al. (1998). It was reported that DEX treatment, either before or after endotoxin injection markedly inhibits temperature because of increased plasma interleukin and prostaglandin. In contrast to this, the non-significant effects on present study probably show the effect of DXM independent to temperature. It is possible that the mild increase in temperature in this study is presumably due to the inhibition or the release of many biologically active substances by
DXM. These results are also consistent with the results reported in the dog (Bughio et al. 2015) and in elephants (Mikota and Plumb 2013).

\section{Residual analysis}

Following DXM administration once daily for three days, noticed its residues in goat milk at 2, 8, 16, 32, 48, 72, 96, 120 and $144 \mathrm{~h}$ (Fig. 2). The present results are supported by previous similar findings of Chen et al. (2011) and Cherlet et al. (2014). Draisci et al. (2001) reported residues of DEX in biological samples i.e., urine, feces, meat, liver or milk in various animals. Besides the clinical usage of DXM in relieving pain and inflammation, its use may result in drug residues in dairy and other products of animal source aimed for human consumption. The present findings are also comparable with previous studies in which several other authors serious threats have been reported for long-term usage of low concentrations of DXM, having adverse effects on public health (Becker 2011; Reig et al. 2016). Additionally, its therapeutic use has also been limited due to the launching of MRLs in milk and edible tissues. DXM is 50 times more powerful than the steroid cortisol (Becker 2011). It has been stated that Fairclough et al. (1981) I.M administration of DXM most probably due to the formation of phosphate and acetate esters which can lead to the sustained release of DXM into the systemic circulation. Coelho et al. (1995) also reported that with the administration of phosphate and acetate esters plasma levels of DEX is also elevated. So, accumulation in plasma or muscles as from I.M. injections, one can surely expect residues in milk. DXM are administered to animals either by injections (parenterally), orally in feed/water, topically on the skin or by intramammary and intrauterine infusions and may lead to residues of drugs in foods of animal origin such as milk, meat, and eggs (Turnipseed et al. 2011). Calves fed milk and/or colostrum's from cows receiving drugs are also included in the cause list of residues (Guest and Paige 1991).

The result of the current study are also consistent with those observed by Falahatpisheh et al. (2011), who reported residues of DXM in cow milk via ELISA. Somewhat similar observations were also noticed by (Caloni et al. 2000; Parmar et al. 2021) who found residues of DEX in lactating cows after administration of a therapeutic dose of DXM once daily, they further stated that recommended doses exceeded the maximum residue limit of DXM and suggested a withdrawal period of 3-3.5 days in order to avoid its residues.

\section{Effects of DEX on goat milk composition}

DXM administration at therapeutic dose i.e., $0.5 \mathrm{mg} / \mathrm{kg} \mathrm{BW}$ once daily for three days, caused a significant increase in Fat content at $48 \mathrm{~h}$ and non-significant at 144 and $168 \mathrm{~h}$ post drug administration (Fig. 3). The fat slowly increased and 
obtained peak level at $48 \mathrm{~h}$ then gradually it returned to decrease at $168 \mathrm{~h}$. It has been reported that due to the lack of negative effect of DEX on fat's fluid secretion increased the concentration of fat in the treated cows (Varner and Johnson 2003). DEX significantly increased protein level at $48 \mathrm{~h}$ in goats and non-significant at $168 \mathrm{~h}$ after drug administration (Fig. 3). The concentration of protein increased then decreased and remained directly proportional to the changes in the milk yield. The secretion of protein was reduced after $48 \mathrm{~h}$. The decline of unwanted effect of DEX on protein on fluid secretion clarifies the increase in the concentration of protein in the treated animals (Varner and Johnson 2003). The present finding for milk protein content was found in contrast to those observed by Shamay et al. (2000). They reported decreased level of protein in milk after induction of DXM in cows. This contrast may be attributed to interspecies differences between cow and goat. Similar findings were also reported by Varner and Johnson (2003) also reported similar finding, he reported that there is decreased level of protein content in milk composition. These variant findings may be due to climatic or nutritional factors which ultimately have caused increased protein level in current study.

The dose of $0.5 \mathrm{mg} / \mathrm{kg} \mathrm{BW}$ of DEX showed a nonsignificant decrease in lactose content post drug administration (Fig. 3). The present findings of lactose content are in agreement with previous findings of Silanikove et al. (2006). They reported decreased level of lactose content in milk following DXM administration in cows. The basic cause in this decreased level of lactose in milk might be due to the relation between the activation of hypothalamic pituitary adrenal axis and reduction in the output of osmotic components from the alveoli into the gland lumen through the production of active biological substance from $\beta$-casein by the plasmin in the milk. This decreased level of lactose also may involve another factor such as decrease secretion of milk from glandular cells which resulted in reversion of lactose level to pre-treatment values in a directly proportional manner (Silanikove et al. 2006).

The therapeutic dose of $0.5 \mathrm{mg} / \mathrm{kg}$ BW of DEX initially exhibited non-significant increase in SNF. Later, SNF significantly increased from 16 to $120 \mathrm{~h}$ and then gradually returned to control level at 144 and $168 \mathrm{~h}$ post treatment (Fig. 3). The present result is in accordance with previous findings in which it has been reported that DXM Residues affected milk composition in various species (Shamay et al. 2000; Thanasak et al. 2004; Macrina et al. 2014). The current result of milk SNF content showed agreement with previous studies where it was also found increased level of SNF content in milk following DXM administration in the cows (Walsh et al. 1981). The basic cause in this increased level of SNF in milk might be due to the genetic potential of individual animals, age, stage of lactation, infections of udder and the type of feeding.

\section{Milk Yield}

In the present study milk yield non-significantly decreased by therapeutic administration of DXM in lactating goats till $16 \mathrm{~h}$. Afterward, a significant decrease was observed in milk yield up to $144 \mathrm{~h}$ then returned to pretreatment level at $168 \mathrm{~h}$ (Fig. 4). Similar observation in agreement was also reported by Shamay et al. (2000), who recorded decreased in milk yield with the administration of a therapeutic dose of DXM in lactating cows. It has been reported that administration of ACTH and DXM to lactating cows caused a proportional decrease in milk yield (Hartmann and Kronfeld 2003). Reportedly, this decrease in milk yield might be due to the disruption of the cellular integrity of mammary epithelial cells of tight junctions which have caused lower milk yield in goats (Stelwagen et al. 2015). Another possible factor in which milk yield decreased may be attributed due to increase in milk sodium and chlorine due to their leakage from blood and decrease in potassium concentration which is leaked from milk to blood due to the administration of DEX (Stelwagen et al. 2014). It has been reported that dexamethasone treatment lowered mammary uptake of glucose, resulted in decreasing milk yield (Shamay et al. 2000).

\section{Conclusion}

It has been concluded from present study that the dexamethasone residues were found in the milk of goat up to $32 \mathrm{~h}$ then gradually decreased up to $168 \mathrm{~h}$. Milk fat and protein increased at in $48 \mathrm{~h}$ then decreased till $168 \mathrm{~h}$. Milk lactose showed non-significant increase which completely returned to pre-medication level at $48 \mathrm{~h}$. Whereas, SNF of milk was increased upto $120 \mathrm{~h}$ and decreased at $168 \mathrm{~h}$. Pulse rate, respiratory rate and rectal temperature increased during initial days later on, returned to control level at $168 \mathrm{~h}$ post DEX administration in goat.

\section{Acknowledgment}

The authors would like to thanks, the Department of Animal Products Technology, Sindh Agriculture University, Tandojam and Veterinary Research Institute Peshawar, Khyber Pakhtunkhwa for providing research facilities. Thank you to all the staff of the laboratories, and guidance throughout the execution of the experiments.

\section{Author Contributions}

MTK carried out the experiments; SB and RB planned the experiments, SS and GM analyzed the data, ZL conceived the experiment; MBA wrote the manuscript.

\section{Conflicts of Interest}

All authors declare no conflicts of interest. 


\section{Data Availability}

The data will be made available on acceptable requests to the corresponding author.

\section{Ethics Approval}

Not applicable.

\section{References}

Barbano DM, JL Clark, CE Dunham, RJ Flemin (1999). Kjeldahl method for determination of total nitrogen content of milk: Collaborative study. J Assoc Off Anal Chem 73:849-859

Becker KL (2011). Principles and practice of endocrinology and metabolism. Lippincott Williams \& Wilkins

Bughio S, T Qureshi, E Daraghmah, M Malhi, A Tunio (2015). Evaluation of clinical and blood biochemical effects of dexamethasone in goat species. Pak J Agric Agric Eng Vet Sci 31:298-307

Caloni F, C Belloli, G Crescenzo, P Ormas, P Archimbault (2000). Determination of dexamethasone in milk of dairy cows by immunoenzymatic assay. Vet Hum Toxic 42:345-348

Chen D, Y Tao, Z Liu, H Zhang, Z Liu, Y Wang, L Huang, Y Pan, D Peng, M Dai, X Wang, Z Yuan (2011). Development of a liquid chromatography-tandem mass spectrometry with pressurized liquid extraction for determination of glucocorticoid residues in edible tissues. J Chromatgr B 879:174-180

Cherlet M, SD Baere, PD Backer (2014). Quantitative determination of dexamethasone in bovine milk by liquid chromatographyatmospheric pressure chemical ionization-tandem mass spectrometry. J Chromatgr B 805:57-65

Coelho MM, G Luheshi, SJ Hopkins, IR Pela, NJ Rothwell (1995). Multiple mechanisms mediate antipyretic action of glucocorticoids. Amer $J$ Physiol Regul Integr Compar Physiol 269:527-535

Draisci R, C Marchiafava, L Palleschi, P Cammarata, S Cavalli (2001). Accelerated solvent extraction and liquid chromatography-tandem mass spectrometry quantitation of corticosteroid residues in bovine liver. J Chromatogr B Biomed Sci Appl 753:217-223

Durand M, ME Mendoza, P Tantivit, A Kugelman, C McEvoy (2002). A randomized trial of moderately early low-dose dexamethasone therapy in very low birth weight infants: Dynamic pulmonary mechanics, oxygenation and ventilation. Pediatrics 109:262-268

Fairclough RJ, JT Hunter, RAS Welch (1981). Dexamethasone concentrations in plasma and milk of cows following the injection of long-and short-acting dexamethasone esters. Aust J Biol Sci 34:313-320

Falahatpisheh H, MA Dabbagh, I Tayebi, M Mahmoudian, H Akbarein, S Rastgoo (2011). A primordial survey of phenylbutazone, dexamethasone and estradiol residues in pasteurized milks of tehran, iran as a potential risk for citizens

Fauser A, F Pohlandt, P Bartmann, L Gortner (1993). Rapid increase of blood pressure in extremely low birth weight infants after a single dose of dexamethasone. Eur J Pediatr 152:354-356

Guest GB, JC Paige (1991). The magnitude of the tissue residue problem with regard to consumer needs. J Amer Vet Med Assoc 5:805-808

Hartmann P, D Kronfeld (2003). Mammary blood flow and glucose uptake in lactating cows given dexamethasone. J Dairy Sci 56:896-902

Ito K, KF Chung, IM Adcock (2006). Update on glucocorticoid action and resistance. J Aller Clin Immunol 117:522-543

Kleyn DH, JM Lynch, DM Barbano, MJ Bloom, MW Mitchell (2001). Determination of fat in raw and processed milks by the Gerber method: collaborative study. J AOAC Intl 84:1499-1508
Kufe DW, RE Pollock, RR Weichselbaum, JCB Jr, TS Gansier, JF Holland (2003). Cancer medicine. American Cancer Society Inc. and BC Decker. Inc., Hamiton, Ontario

Li X, X Chen, J Wu, Z Liu, J Wang, C Song, S Zhao, H Lei, Y Sun (2021). Portable, rapid, and sensitive time-resolved fluorescence immunochromatography for on-site detection of dexamethasone in milk and pork. Foods 10:1339

Macrina AL, ACW Kauf, DA Pape-Zambito, RS Kensinger (2014). Induced lactation in heifers: Effects of dexamethasone and age at induction on milk yield and composition. J Dairy Sci 97:1446-1453

Mikota SK, DC Plumb (2013). Doramectin. In: Elephant Care Int. Junio: https://www.facebook.com/ElephantCareInternational/ (Accessed: 22 January 2022)

Ohlsson A, SA Calvert, M Hosking, AT Shennan (1992). Randomized controlled trial of dexamethasone treatment in very-low-birth-weight infants with ventilator-dependent chronic lung disease. Acta Paediatr $81: 751-756$

Parmar JK, KK Chaubey, V Gupta, MN Bharath (2021). Assessment of various veterinary drug residues in animal originated food products. Vet World 14:1650-1664

Reig M, L Mora, JL Navarro, F Toldra (2016). A chromatography method for the screening and confirmatory detection of dexamethasone. Meat Sci 74:676-680

Roadhouse CL, JL Henderson (1950). The Market-milk Industry. 2nd Edn. Magraw Hill Brok Company, New York, USA

Shamay A, F Shapiro, H Barash, I Bruckental, N Silanikove (2000). Effect of dexamethasone on milk yield and composition in dairy cows. Ann Zootech 49:343-352

Silanikove N, A Shamay, D Shinder, A Moran (2006). Stress down regulates milk yield in cows by plasmin induced $\beta$-casein product that blocks $\mathrm{K}^{+}$channels on the apical membranes. Life $\mathrm{Sci}$ 67:2201-2212

Sousa C (2005). The use of corticosteroids in veterinary dermatology. $J$ Dermatol 85:10-12

Stelwagen K, VC Farr, SR Davis, CG Prosser (2015). EGTA-induced disruption of epithelial cell tight junctions in the lactating caprine mammary gland. Amer J Physiol-Regul Integr Compar Physiol 269:848-855

Stelwagen K, S Davis, V Farr, C Prosser, R Sherlock (2014). Mammary epithelial cell tight junction integrity and mammary blood flow during an extended milking interval in goats. J Dairy Sci 77:426-432

Thanasak J, R Jorritsma, A Hoek, JP Noordhuizen, VP Rutten, KE Muller (2004). The effects of a single injection of dexamethasone-21isonicotinate on the lymphocyte functions of dairy cows at two weeks post partum. Vet Res 35:103-112

Turnipseed SB, JM Storey, SB Clark, KE Miller (2011). Analysis of veterinary drugs and metabolites in milk using quadrupole time-offlight liquid chromatography- mass spectrometry. J Agric Food Chem 59:7569-7581

Varner M, B Johnson (2003). Influence of adrenocorticotropin upon milk production, milk constituents, and endocrine measures of dairy cows. J Dairy Sci 66:458-465

Walsh JP, J Connolly, MG Fleming, M Keane, TCA McGann, GJ Ferrall (1981). Chemical Composition of Milk in Ireland.

Washburn BE, JJ Millspaugh, JH Schulz, SB Jones, T Mong (2003). Using fecal glucocorticoids for stress assessment in mourning doves. Condor 105:696-706

Yared JP, NJ Starr, L Hoffman-Hogg, CA Bashour, SR Insler, M Connor, M Piedmonte, DM Cosgrove (1998). Dexamethasone decreases the incidence of shivering after cardiac surgery: a randomized, doubleblind, placebo-controlled study. Anesth Analg 87:795-799

Zimmermann H, DS Gardner, JK Jellyman, AL Fowden, DA Giussani, AJ Forhead (2003). Effect of dexamethasone on pulmonary and renal angiotensin-converting enzyme concentration in fetal sheep during late gestation. Amer J Obst Gynecol 189:1467-1471 